\title{
Enhancement of activity of PtRh nanoparticles towards oxidation of ethanol through modification with molybdenum oxide or tungsten oxide
}

\author{
Krzysztof Miecznikowski
}

Received: 8 November 2011 /Revised: 17 February 2012 / Accepted: 20 February 2012 /Published online: 3 March 2012

(C) The Author(s) 2012. This article is published with open access at Springerlink.com

\begin{abstract}
Electrocatalytic systems utilizing carbon (Vulcan)supported PtRh nanoparticles ( $\mathrm{PtRh} /$ Vulcan) admixed with either molybdenum oxide or tungsten oxide were tested and compared during electrooxidation of ethanol. The systems' performance was diagnosed using electrochemical techniques such as voltammetry and chronoamperometry. The proposed electrocatalytic materials were also characterized with X-ray diffraction (XRD), transmission and scanning electron microscopies (TEM and SEM), as well as SEM-coupled energy dispersive X-ray spectroscopy (SEM-EDX). For both systems containing molybdenum and tungsten oxides, enhancements in catalytic activities (relative to the behavior observed at bare $\mathrm{PtRh} /$ Vulcan nanoparticles) were found during ethanol electrooxidation at room temperature $\left(22^{\circ} \mathrm{C}\right)$. Further, it was from chronoamperometric current (density)-time responses that anodic electrocatalytic currents measured at $0.3 \mathrm{~V}$ (vs. RHE) were more than $20 \%$ higher in the case of the $\mathrm{MoO}_{3}$-containing PtRh/Vulcan system relative to that utilizing $\mathrm{WO}_{3}$. The diagnostic "CO-stripping" experiments were consistent with the view that addition of molybdenum oxide or tungsten oxide to $\mathrm{PtRh} / \mathrm{Vulcan}$ tended to shift potential for the oxidation of inhibiting CO-adsorbate ca. 80 or $40 \mathrm{mV}$ towards less negative values in comparison to the analogous but oxide-free system. The fact that carbon (Vulcan)-supported PtRu nanoparticles exhibited higher electrocatalytic reactivity observed phenomena may be attributed to specific interactions between noble metal centers and the oxides in addition to chemical
\end{abstract}

K. Miecznikowski $(\triangle)$

Department of Chemistry, University of Warsaw,

Pasteura 1,

PL-02-093 Warsaw, Poland

e-mail:kmiecz@chem.uw.edu.pl reactivity of metal oxo groups in the vicinity of $\mathrm{PtRh} /$ Vulcan at the electrocatalytic interface.

Keywords Bimetallic PtRh nanoparticles · Molybdenum oxide $\cdot$ Tungsten oxide $\cdot$ Ethanol oxidation $\cdot$ Electrocatalysis

\section{Introduction}

Fuel cell technology has become increasingly significant during recent years because of growing industrialization and related energy consumption, problems with environmental protection as well as limited resources of fossil fuels. Hence, it is important to find new energy sources that are thermally efficient and environmentally friendly. In this context, fuel cells are an alternative to conventional energy devices because of their potentially high thermodynamic efficiency and environmentally benign products $[1,2]$.

Many organic compounds have been used as fuels for polymer electrolyte membrane fuel cells, but usually methanol $[3,4]$ and, more recently, ethanol are considered [5-10]. In the latter case, the complete oxidation of ethanol produces as many as 12 electrons, but relative to methanol, the oxidation process is a fairly complex reaction because it requires dissociation of the $\mathrm{C}-\mathrm{C}$ bond. The literature data show that, at present, the platinum-based catalysts are the most effective systems for adsorptive activation and dissociation of organic molecules [11-13]. However, the activity of $\mathrm{Pt}$ for the electrooxidation of ethanol is poor because the reaction rate on $\mathrm{Pt}$ is slow and the main products are not $\mathrm{CO}_{2}$ but rather acetaldehyde and acetic acid $[14,15]$. In other words, the bare Pt catalyst has effectively no sufficient ability to break the $\mathrm{C}-\mathrm{C}$ bond. It is reasonable to expect that fabrication of Pt-based multicomponent systems, by appropriate alloying of interfacial modification, may lead to the 
improvement of electrocatalytic activity during the electrooxidation of ethanol.

Previous studies indicate that the presence of a second transition metal such as $\mathrm{Ru}, \mathrm{Rh}, \mathrm{Ir}, \mathrm{Sn}, \mathrm{Pd}, \mathrm{Zr}, \mathrm{Mo}, \mathrm{W}$, or $\mathrm{Pb}$ $[4,9,10,16-22]$ into $P t$ led to the electrooxidation of ethanol at lower potentials than on pure platinum. The sizeable enhancement was observed in the case of carbon-supported or intentionally decorated Pt-Sn catalysts [9, 10, 23-25], but in all cases, the main products formed were still acetic acid and acetaldehyde [26-28]. A report by Souza's group [11] showed that the presence of small amounts of Rh in Pt-based catalysts played an important role in improving the $\mathrm{C}-\mathrm{C}$ bond cutting, and it tended to increase the ratio of $\mathrm{CO}_{2}$ to acetaldehyde in the oxidation products. On the other hand, the obtained electrocatalyst was not highly efficient for the electrooxidation of ethanol. More recently, Kowal et al. [8, 29] have described a ternary electrocatalyst utilizing PtRh within carbon-supported $\mathrm{SnO}_{2}$; the system has yielded promising results for the electrooxidation of ethanol. On the whole, it seems that a combination of three components ( $\mathrm{Pt}, \mathrm{Rh}$, and $\mathrm{SnO}_{2}$ ) tends to improve the oxidation reaction rate $[8,29]$. From another point of view, $\mathrm{SnO}_{2}$ seems to provide a good environment for PtRh nanoparticles. What is even more important, bimetallic PtRh nanostructured catalysts seem to be less prone to oxidative degradation than PtSn or even PtRu ones.

Historically, in the case of methanol electrooxidation, the activity of the electrocatalyst was improved by the addition of molybdenum or tungsten in various forms (elements or metal oxides) as a second or third constituent [30-33]. Molybdenum oxide and tungsten oxide have been demonstrated to show a promoting effect on Pt-based catalysts towards the oxidation of $\mathrm{CO}$, thereby mitigating $\mathrm{CO}$ poisoning [34-36] that also constitutes a limiting factor during oxidation of methanol [37-39]. The improvement of catalytic activities of systems containing molybdenum and tungsten oxide for $\mathrm{CO}$ electrooxidation was also confirmed by theoretical studies [40, 41]. When it comes to oxidation of ethanol, modification of PtSn nanoparticles with polymolybdates or polytungstates [9, 42-44], with tungsten oxide [10] or molybdenum oxide [31], has also resulted in the enhancement of the system's electrocatalytic properties.

It has been recently postulated that metal oxide species stabilize noble metal nanoparticle dispersions [10, 45], and they have the ability to produce $\mathrm{OH}^{-}$surface groups (from electrodissociation of water) that facilitate the $\mathrm{CO}$ electrooxidation process $[46,47]$. The latter point is important in the context of electrooxidation of small organic molecules.

In this work, the electrocatalytic activity of carbonsupported $\mathrm{PtRh}$ nanoparticles $(\mathrm{PtRh} / \mathrm{C})$, that have been intentionally modified or admixed with metal oxide species such as $\mathrm{MoO}_{3}$ or $\mathrm{WO}_{3}$, is investigated for the electrooxidation of ethanol. In addition, general physicochemical properties of the proposed catalysts are described.

\section{Experimental}

All chemicals obtained were commercial materials of analytical grade purity. The $\mathrm{PtRh} / \mathrm{Vulcan}$ nanoparticles $(20 \%$ on Vulcan XC-72, Pt/Rh-4:1) were from BASF Fuel Cell Inc. Solutions were prepared using doubly distilled and subsequently de-ionized (Millipore Milli-Q) water. Argon was used to de-aerate the solutions and to keep an oxygen-free atmosphere over the solution during the measurements. Morphology of the catalytic particles was monitored using a LIBRA 120 transmission electron microscope (TEM) operating at $120 \mathrm{kV}$. Samples for TEM measurements were prepared by placing a drop $(1-2 \mu \mathrm{l})$ of the solution of carbon-supported nanoparticles onto Fromvar film grids (Agar Scientific) and, later, by subjecting them to drying on 400-mesh Cu. Moreover, the morphology and the composition of catalytic films were assessed using a Nova 200 NanoSEM high-resolution scanning electron microscope equipped with energy dispersive X-ray spectrometry (EDS, Genesis XM4) analyzer. X-ray diffraction (XRD) patterns of the catalysts were obtained with a Bruker D8 Discover system operated with a Cu lamp $(1.54 \AA)$ and Vantec (linear) detector $(k=1.5406 \AA)$.

All electrochemical measurements were performed using $\mathrm{CH}$ Instruments $750 \mathrm{~A}$ workstations in a three-electrode configuration. The reference electrode was a $\mathrm{K}_{2} \mathrm{SO}_{4}$ saturated mercury/mercury sulfate electrode $\left(\mathrm{Hg} / \mathrm{Hg}_{2} \mathrm{SO}_{4}\right)$, and a carbon rod was the counter electrode. All potentials in the present work were recalculated and expressed versus the reversible hydrogen electrode (RHE). As a rule, glassy carbon electrode was the base for the working electrode (geometric area, $0.071 \mathrm{~cm}^{2}$ ). The catalyst layer was fabricated through the modification of the glassy carbon by immobilization of $\mathrm{PtRh} /$ Vulcan nanoparticles. To prepare the solution of tungstic acid or molybdic acid, the suitable aqueous solution of $0.05 \mathrm{~mol} \mathrm{dm}{ }^{-3} \mathrm{Na}_{2} \mathrm{WO}_{4}$ or $\mathrm{Na}_{2} \mathrm{MoO}_{4}$ was passed through a proton exchange resin, Dowex 50 WX2-200. The suspension of Vulcan-supported PtRh nanoparticles ( $\mathrm{PtRh} /$ Vulcan) was prepared as follows: a known amount $(10 \mathrm{mg})$ of PtRh/Vulcan nanoparticles was dispersed in $2 \mathrm{~cm}^{3}$ of $0.05 \mathrm{~mol} \mathrm{dm}{ }^{-3}$ aqueous solution of tungstic acid or molybdic acid. The suspension was mixed using magnetic stirring for $24 \mathrm{~h}$ and centrifuged. Then the supernatant solution was replaced with water, and a stable suspension of $\mathrm{WO}_{3}$ or $\mathrm{MoO}_{3}$-modified $\mathrm{PtRh} /$ Vulcan nanoparticles were produced. In the final suspension, the approximate molar ratio of $\mathrm{Pt}$ to tungsten oxide or molybdenum oxide (dehydrated) was 1 to 1 . To immobilize catalytic nanoparticles, a $5-\mu l$ aliquot of the suspension was dropped using a micropipette on the glassy carbon electrode surface. The resulting layer was air-dried for $30 \mathrm{~min}$ at room temperature $\left(22{ }^{\circ} \mathrm{C}\right)$. Then $2 \mu \mathrm{l}$ of Nafion $(0.02 \%$ alcoholic solution) was dropped on top of the modified glassy carbon 
electrode. The Nafion film was sufficiently stable to fix the modified and unmodified catalytic nanoparticles on the electrode substrate in the supporting electrolyte. As a rule, the catalytic electrodes were conditioned through the application of 25 complete oxidation/reduction cycles at $50 \mathrm{mV} \mathrm{s}^{-1}$ between 0 and $0.8 \mathrm{~V}$ in $0.5 \mathrm{~mol} \mathrm{dm}^{-3} \mathrm{H}_{2} \mathrm{SO}_{4}$. The total loading of PtRh nanoparticles was approximately $160 \mu \mathrm{g} \mathrm{cm}^{-2}$.

The CO-stripping measurements were performed in $0.5 \mathrm{~mol} \mathrm{dm}^{-3} \mathrm{H}_{2} \mathrm{SO}_{4}$ electrolyte using the glassy carbon substrate onto which surface the appropriate catalyst was introduced. The electrolyte was first de-oxygenated by purging argon for $30 \mathrm{~min}$. Subsequently, a few consecutive voltammetric scans (at $50 \mathrm{mV} \mathrm{s}^{-1}$ ) were recorded in the potential range from 0.0 to $0.8 \mathrm{~V}$. To saturate the solution with $\mathrm{CO}$ gas, pure CO (from Air Liquide) was bubbled through the electrolyte for $10 \mathrm{~min}$. The actual CO-adsorption step (on the surface of catalytic Pt nanocenters) was achieved upon application of the potential of $0.1 \mathrm{~V}$ for $5 \mathrm{~min}$ after which the electrolyte was purged with argon for $30 \mathrm{~min}$ under open-circuit conditions to remove dissolved $\mathrm{CO}$. As a rule, three cyclic voltammetric scans (at $10 \mathrm{mV} \mathrm{s}^{-1}$ ) were recorded in the potential range from 0.0 to $0.9 \mathrm{~V}$. Most of the experiments using these catalysts were performed two to three times with freshly prepared electrodes to ensure the reproducibility of electrode preparation and performance.

\section{Results and discussion}

Structure and morphology PtRh/Vulcan catalysts

To get some insight into the structure and morphology of the $\mathrm{PtRh} /$ Vulcan nanoparticles modified with molybdenum and tungsten oxides, the samples were examined by XRD (Fig. 1). The first broad diffraction peak at $25.0^{\circ}$, which appeared in all the XRD patterns, corresponded to the hexagonal carbon support [48]. In the case of unmodified PtRh/ Vulcan nanoparticles (Fig. 1a), three characteristic diffraction peaks appear, which are all clearly broadened, indicating a very small average particle size [49, 50]. Moreover, for all samples, we had no direct evidence for the presence of diffraction peaks that could be attributed to rhodium (PCPDF 05-0685) because they are characterized by diffraction peak positions and crystalline structures $[29,51]$ similar to platinum (PCPDF 040802). These XRD data do not allow clear identification of the phase composition of the metal. The diffractogram of the $\mathrm{MoO}_{3}$-modified PtRh/Vulcan electrocatalyst (Fig. 1b) showed three peaks that appeared almost at the same position as for unmodified $\mathrm{PtRh} /$ Vulcan nanoparticles, but no diffraction peaks characteristic of $\mathrm{MoO}_{3}$ were observed (PCPDF 50508). Indeed, the pattern of the $\mathrm{MoO}_{3} /$ Vulcan sample that had been prepared in the same way showed only the broad

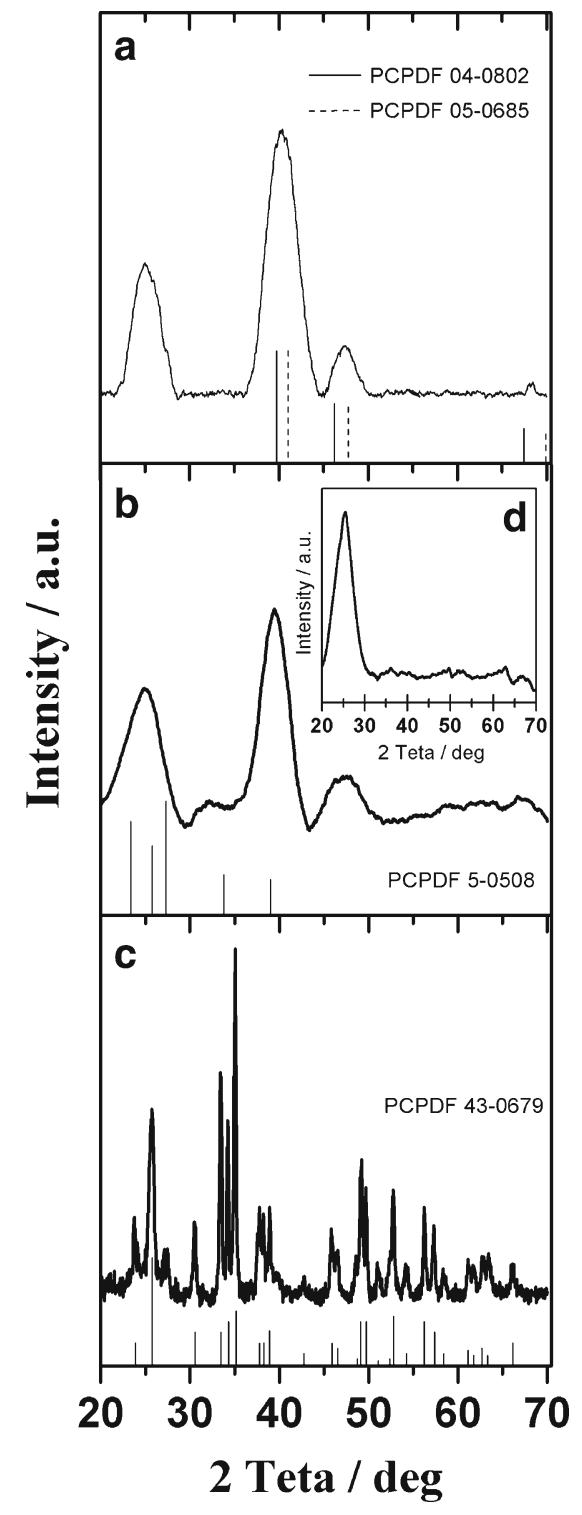

Fig. 1 XRD images of PtRh/Vulcan (a), $\mathrm{MoO}_{3}$-modifed PtRh/Vulcan (b), $\mathrm{WO}_{3}$-modifed PtRh/Vulcan (c), and $\mathrm{MoO}_{3}$-modifed Vulcan (d)

diffraction peaks corresponding to the carbon support materials (Fig. 1, inset D). It is reasonable to expect that, in both cases, molybdenum species did not form crystalline aggregates [52]. In the case of $\mathrm{WO}_{3}$-modifed $\mathrm{PtRh} /$ Vulcan catalysts, the signals characteristic of $\mathrm{WO}_{3}$ were clearly visible in the XRD pattern (Fig. 1c) (PCPDF 43-0679). The $\mathrm{WO}_{3}$ phase had characteristic peaks attributable to monoclinic $\mathrm{WO}_{3}$. The observation is in accord with earlier reports [53,54]. The diffraction peaks in the $\mathrm{WO}_{3}$-modified PtRh/Vulcan nanoparticles (Fig. 1c) were narrower in contrast to those in the unmodified and $\mathrm{MoO}_{3}$-modified $\mathrm{PtRh} / \mathrm{Vulcan}$ electrocatalyst where the diffraction peaks (Fig. 1a and b) were broadened.

In order to get more information about the particle size and the distribution of nanoparticles on the carbon material, TEM analysis was performed. Figure 2 shows the TEM images for 

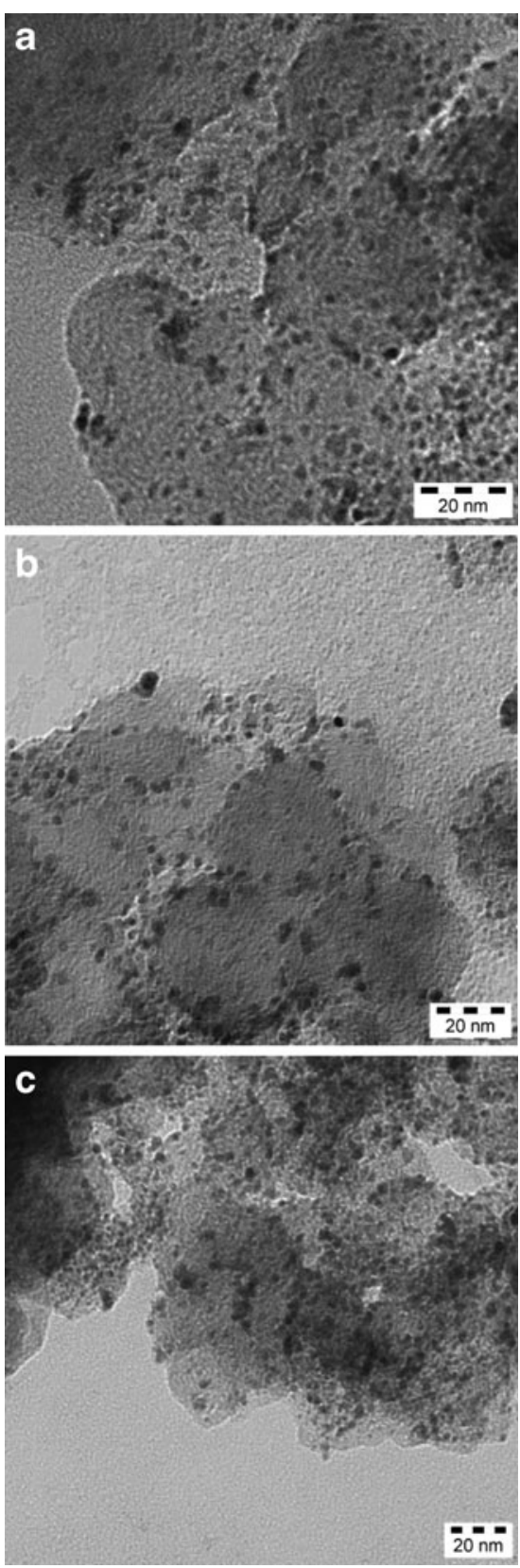

Fig. 2 Low-magnification TEM images of $\mathrm{PtRh} / \mathrm{Vulcan}(\mathbf{a}), \mathrm{MoO}_{3^{-}}$ modifed PtRh/Vulcan (b), and $\mathrm{WO}_{3}$-modifed PtRh/Vulcan (c) nanoparticles

$\mathrm{PtRh} /$ Vulcan, $\mathrm{MoO}_{3}$-modified PtRh/Vulcan, and $\mathrm{WO}_{3}$-modified $\mathrm{PtRh} /$ Vulcan nanoparticles. Low-magnification images show that approximately spherical bimetallic nanoparticles are in all cases uniformly dispersed on the surface of carbon (Vulcan XC-72R) supports, and the distribution lies in a narrow particle size range. Histograms of the particle size distribution (not shown), which reflect analyses of several different portions of the catalysts, are also consistent with a uniform distribution of these catalysts. As can be seen in Fig. 2, both the obtained materials have small particle sizes narrowly distributed in the range ca. $2-6 \mathrm{~nm}$.
Figure 3 shows SEM images and EDS spectra of the electrocatalytic materials (a) $\mathrm{PtRh} / \mathrm{Vulcan}$, (b) $\mathrm{MoO}_{3}$-modified $\mathrm{PtRh} / \mathrm{Vulcan}$, and (c) $\mathrm{WO}_{3}$-modified $\mathrm{PtRh} /$ Vulcan nanoparticles following deposition on glassy carbon substrates and finally covered by the thin layer of Nafion. In all cases, the particles are primarily distributed in the range 50 to $100 \mathrm{~nm}$, which is attributed to Vulcan (carbon) support; the white small spots (diameters below $10 \mathrm{~nm}$ ) originate from $\mathrm{PtRh}$ nanoparticles, which are approximately spherical and uniformly distributed. The SEM measurements are in good agreement with TEM results. Figure 3 also shows the EDS for which peaks are assigned to $\mathrm{W}, \mathrm{Pt}$, $\mathrm{Rh}$, and Mo. It is clear that $\mathrm{W}$ and Mo exist in the metal oxide-modified catalytic material at approximately 3 at $\%$ and 4 at $\%$ levels, respectively. To validate our EDS-based estimations, molar contents of metal oxides $\left(\mathrm{MoO}_{3}, \mathrm{WO}_{3}\right)$ have been addressed by using Raman spectrometry with an internal standard $\left(\mathrm{KNO}_{3}\right)$ as proposed by Hercules [55]. The obtained results allow me to state with a large degree of certainty that, in both cases, the molar contents $\mathrm{MoO}_{3}$ and $\mathrm{WO}_{3}$ (relative to $\mathrm{Pt} / \mathrm{Rh}$ ) have not been larger than $10 \%$.

Electrochemical behavior in the absence and presence of ethanol

Typical cyclic voltammetric curves obtained for the PtRh/ Vulcan, $\mathrm{MoO}_{3}$-modifed $\mathrm{PtRh} /$ Vulcan, and $\mathrm{WO}_{3}$-modifed $\mathrm{PtRh} /$ Vulcan nanoparticles deposited on glassy carbon electrode from $0.5 \mathrm{~mol} \mathrm{dm}^{-3}$ sulfuric acid are shown in Fig. 4. The voltammograms for unmodified $\mathrm{PtRh} /$ Vulcan display prominent single peaks in the hydrogen adsorption region (0.0-0.4 V vs. RHE) [56]. These are probably related to hydrogen adsorption/desorption on an intermetallic alloy phase. The currents in the double-layer region between 0.4 and $0.8 \mathrm{~V}$ vs. RHE are significant. This behavior is characteristic of carbon-supported binary electrocatalysts containing transition metals [57]. Cyclic voltammetry of the $\mathrm{MoO}_{3}$ modified $\mathrm{PtRh} /$ Vulcan system shows similar behavior to that described above for both hydrogen absorption/desorption and for currents in the double-layer region between 0.5 and $0.8 \mathrm{~V}$. However, in the potential range from 0.3 to $0.5 \mathrm{~V}$, an additional peak appears (Fig. 4; A, curve b). For comparison, the cyclic voltammogram of $\mathrm{MoO}_{3}$-modified Vulcan support materials introduced onto the glassy carbon surface is also provided (Fig. 4, B). It is interesting to note that the peaks are at about $0.4 \mathrm{~V}$ (Fig. 4; A, curve b) for $\mathrm{MoO}_{3}$-modified $\mathrm{PtRh} /$ Vulcan, i.e., at potentials less negative than the analogous peak current observed on bare $\mathrm{MoO}_{3} /$ Vulcan (Fig. 4, B). The peak, which is observed at about $0.4 \mathrm{~V}$ (Fig. 4; A, curve b), is in agreement with earlier reports describing redox processes involving $\mathrm{Mo}(\mathrm{V})$ and $\mathrm{Mo}$ (VI) [40, 58-61]. Moreover, the presence of $\mathrm{MoO}_{3}$ leads to an increase in the voltammetric peaks for hydrogen 
Fig. 3 Scanning electron microscopy and EDS analysis of a PtRh/Vulcan, b $\mathrm{MoO}_{3}$ modifed $\mathrm{PtRh} / \mathrm{Vulcan}$, and $\mathbf{c}$ $\mathrm{WO}_{3}$-modifed PtRh/Vulcan nanoparticles
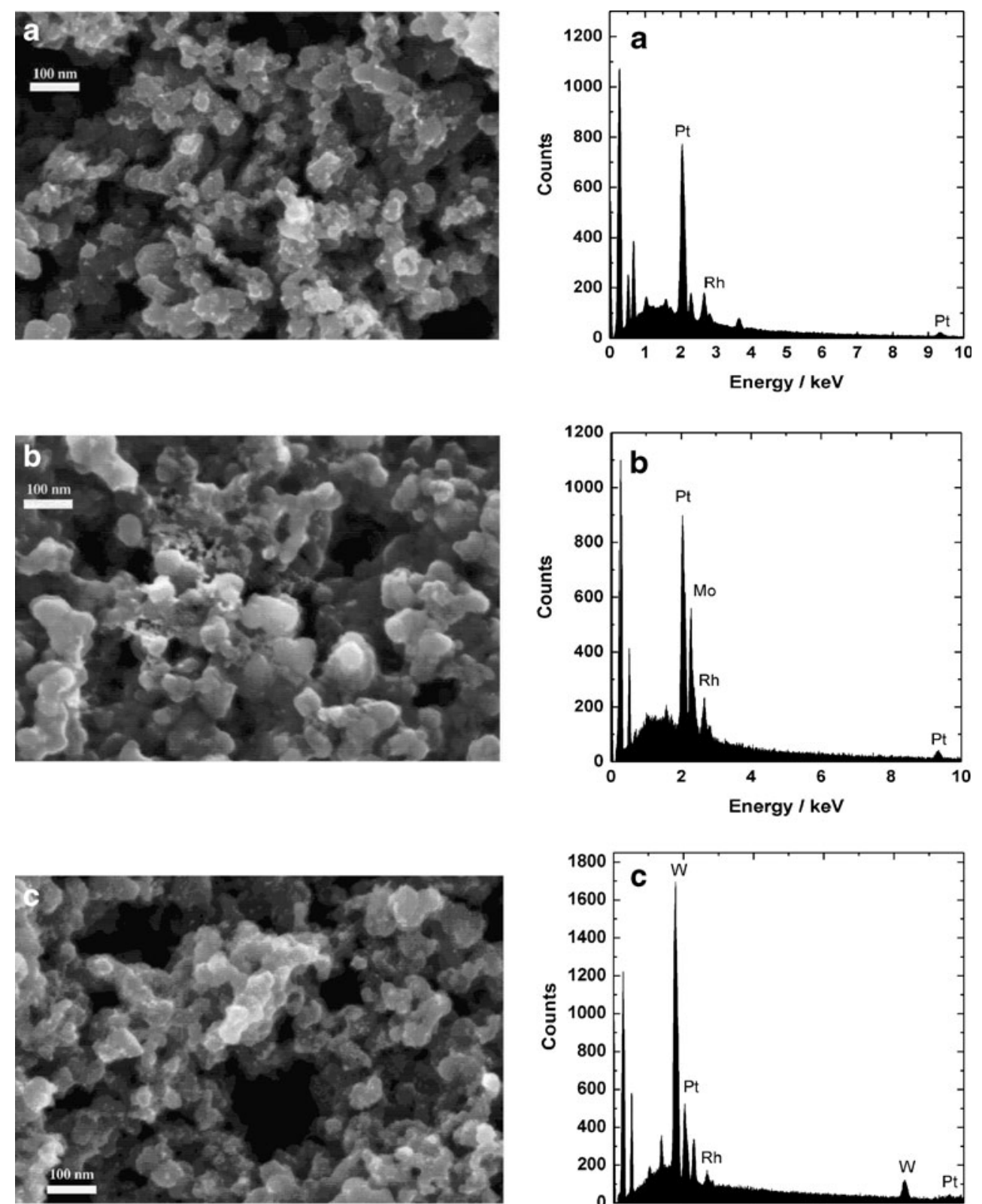

adsorption and desorption, which are presumably due to the hydrogen spillover effect within the hydrogen molybdenum bronze. This phenomenon has been attributed to the interaction between the platinum active sites and molybdenum oxides [37]. By comparing the results of $\mathrm{PtRh} / \mathrm{Vulcan}$ (Fig. 4; A, curve a) to those of $\mathrm{WO}_{3}$-modifed $\mathrm{PtRh} / \mathrm{Vulcan}$ materials (Fig. 4; A, curve c), one can observe that the modification by $\mathrm{WO}_{3}$ results in the development of two peaks in the hydrogen adsorption/desorption region. The new peak appears at a higher potential. It perhaps originates from the adsorption of tungsten oxide $\left(\mathrm{WO}_{3}\right)$, but this conjecture is not readily confirmed by voltammetry because the formation of hydrogen tungsten bronze and the reversal of $\mathrm{WO}_{3}$ overlap the hydrogen absorption and desorption peaks.
A clear distinction between these two catalytic systems is that the hydrogen adsorption/desorption region is higher for $\mathrm{WO}_{3}$-modified $\mathrm{PtRh} / \mathrm{Vulcan}$ than that for the $\mathrm{PtRh} /$ Vulcan catalyst.

The stability of both obtained catalytic materials has been studied under 1-h chronoamperometric and repetitive (50 cycles) voltammetric measurements in the presence of ethanol (for simplicity, not shown here). The results are consistent with the view that $\mathrm{PtRh} / \mathrm{Vulcan}$ nanoparticles exhibit good stability (8\%) in the $0-900-\mathrm{mV}$ (vs. RHE) potential range. Consequently, this potential range has been further utilized during electrochemical measurements for $\mathrm{WO}_{3}$ - or $\mathrm{MoO}_{3}$-modified PtRh/Vulcan nanoparticles. The potential practical problem concerns the limited stability of $\mathrm{MoO}_{3}$ in 


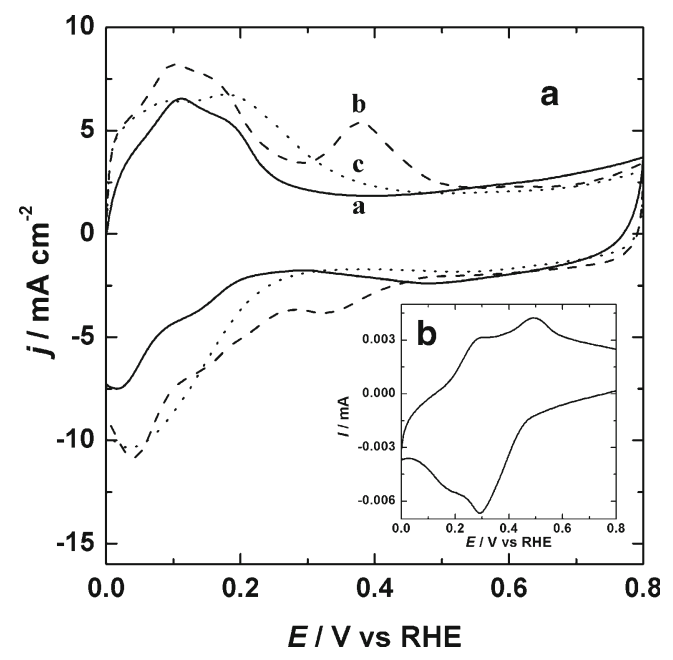

Fig. $4 A$ Cyclic voltammetric responses of PtRh/Vulcan $(a), \mathrm{MoO}_{3^{-}}$ modifed $\mathrm{PtRh} /$ Vulcan $(b)$, and $\mathrm{WO}_{3}$-modifed $\mathrm{PtRh} /$ Vulcan $(c)$ catalytic systems. $B$ Cyclic voltammetric responses of $\mathrm{MoO}_{3}$-modifed Vulcan. Electrolyte, $0.5 \mathrm{~mol} \mathrm{dm}^{-3} \mathrm{H}_{2} \mathrm{SO}_{4}$. Scan rate, $10 \mathrm{mV} \mathrm{s}^{-1}$

the proposed electrocatalytic system due to possible dissolution of the $\mathrm{MoO}_{3}$ from the surface of carbon-supported $\mathrm{PtRh}$ nanoparticles. In the literature, the stability of $\mathrm{MoO}_{3}$ is still controversial [62-67]. However, we have not observed any time-dependent deactivation effect that may imply dissolution of $\mathrm{MoO}_{3}$. In the case of $\mathrm{WO}_{3}$-modified $\mathrm{PtRh} / \mathrm{Vul}$ can nanoparticles, no dissolution of the metal oxide is expected. During chronoamperometric measurements pursued for $1 \mathrm{~h}$, effective decreases of steady-state catalytic currents have never exceeded $12 \%$ in the case of both tungsten and molybdenum oxides. At this stage, practical stability of the system is rather low, but the present data have fundamental importance. Knowing the possibility of forming more robust $\mathrm{WO}_{3}$ structures at temperatures exceeding $100{ }^{\circ} \mathrm{C}$, further research along this line is necessary.

Figure 5 shows representative cyclic voltammograms obtained in the presence of $0.5 \mathrm{M}$ ethanol at a glassy carbon electrode modified with PtRh/Vulcan (Fig. 5; A, curve a), $\mathrm{MoO}_{3}$-modified PtRh/Vulcan (Fig. 5; A, curve b), and $\mathrm{WO}_{3}$-modifed PtRh/Vulcan (Fig. 5; A, curve c). The shapes of curves are typical for the electrooxidation reactions of organic alcohols; specifically, there are two peaks in both forward and reverse scans as reported in the literature [56, 68-70]. Most likely, the first (least positive) anodic peak reflects primarily the oxidation of ethanol to $\mathrm{CO}_{2}$; in a given scan, there may be some contribution to this current from incompletely oxidized carbonaceous species formed during the prior cycle. What is more important is that the onset potential for ethanol electrooxidation is decreased in comparison to that at bare $\mathrm{PtRh} / \mathrm{Vulcan}$ by modification of the catalyst with $\mathrm{MoO}_{3}$ or $\mathrm{WO}_{3}$ by ca. 100 or $70 \mathrm{mV}$ (Fig. 5, A), respectively. In both cases, the current densities are higher

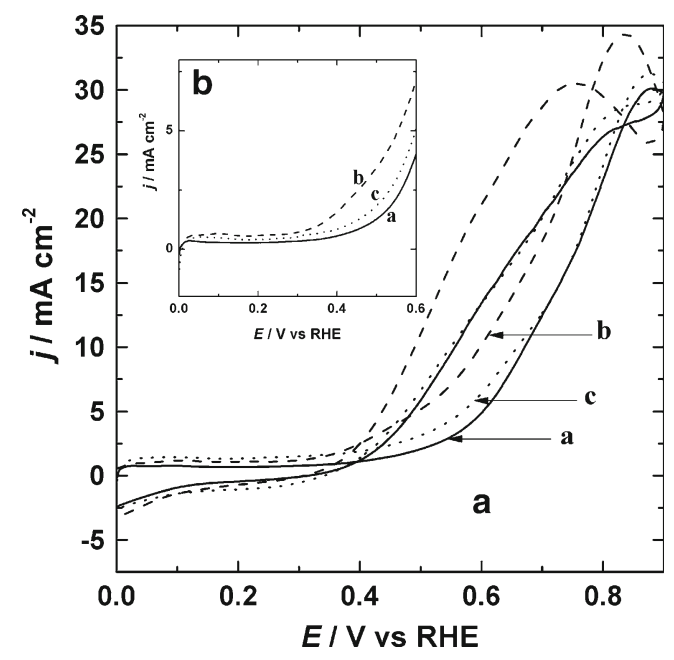

Fig. $5 A$ Cyclic voltammetric responses for oxidation of $0.5 \mathrm{~mol} \mathrm{dm}^{-3}$ ethanol at $\mathrm{PtRh} / \operatorname{Vulcan}(a), \mathrm{MoO}_{3}$-modifed $\mathrm{PtRh} / \mathrm{Vulcan}(b)$, and $\mathrm{WO}_{3}$-modifed PtRh/Vulcan $(c)$ catalysts. $B \mathrm{LSV}$ responses for the oxidation of $0.5 \mathrm{~mol} \mathrm{dm}{ }^{-3}$ ethanol at $\mathrm{PtRh} /$ Vulcan $(a), \mathrm{MoO}_{3}$-modifed $\mathrm{PtRh} /$ Vulcan $(b)$, and $\mathrm{WO}_{3}$-modifed $\mathrm{PtRh} /$ Vulcan $(c)$ catalyst. Electrolyte, $0.5 \mathrm{~mol} \mathrm{dm}^{-3} \mathrm{H}_{2} \mathrm{SO}_{4}$. Scan rate, $10 \mathrm{mV} \mathrm{s}^{-1}$

over the entire potential range, confirming the beneficial effect of these metal oxides on the electrocatalytic oxidation of ethanol. The observation can be interpreted in terms of the activation role of either $\mathrm{MoO}_{3}$ or $\mathrm{WO}_{3}$ on the interfacial water molecules at potentials lower than those expected for unmodified $\mathrm{PtRh} /$ Vulcan electrocatalysts [10]. In other words, the presence of $\mathrm{MoO}_{3}$ or $\mathrm{WO}_{3}$ on $\mathrm{PtRh} / \mathrm{Vulcan}$ nanoparticles tends to enhance electrooxidation of ethanol in comparison to unmodified $\mathrm{PtRh} / \mathrm{Vulcan}$ electrocatalysts.

The inset to Fig. 5 (Fig. 5, B) illustrates backgroundsubtracted linear scan voltammograms (LSVs) for $0.5 \mathrm{M}$ ethanol in $0.5 \mathrm{M} \mathrm{H}_{2} \mathrm{SO}_{4}$ at glassy carbon electrodes modified with PtRh/Vulcan (Fig. 5; B, curve a), $\mathrm{MoO}_{3}$-modified PtRh/Vulcan (Fig. 5; B, curve b), and $\mathrm{WO}_{3}$-modifed PtRh/ Vulcan (Fig. 5; B, curve c). The voltammograms show welldefined peaks for the anodic processes, thereby allowing refinement of the values of the potentials for the onset of ethanol oxidation. The onset potentials at bare $\mathrm{PtRh} / \mathrm{Vulcan}$ nanoparticles and at $\mathrm{MoO}_{3}$-modified and $\mathrm{WO}_{3}$-modified $\mathrm{PtRh} /$ Vulcan nanoparticles were $0.41,0.36$, and $0.30 \mathrm{~V}$, respectively, which again illustrates the enhancement of the catalytic activity for the $\mathrm{MoO}_{3}$ system even in comparison to the $\mathrm{WO}_{3}$-modified system and, particularly, to unmodified nanoparticles.

Activities of these electrodes towards the electrocatalytic oxidation of ethanol were compared by chronoamperometry at two applied potentials and with current densities recorded using the geometric areas of the electrodes (Fig. 6). In agreement with the cyclic voltammetry described above, the catalytic current density obtained, when the $\mathrm{PtRh} / \mathrm{Vulcan}$ nanoparticles were modified with $\mathrm{MoO}_{3}$, was increased at both 0.3 and $0.4 \mathrm{~V}$ in comparison to $\mathrm{WO}_{3}$-modified and unmodified 

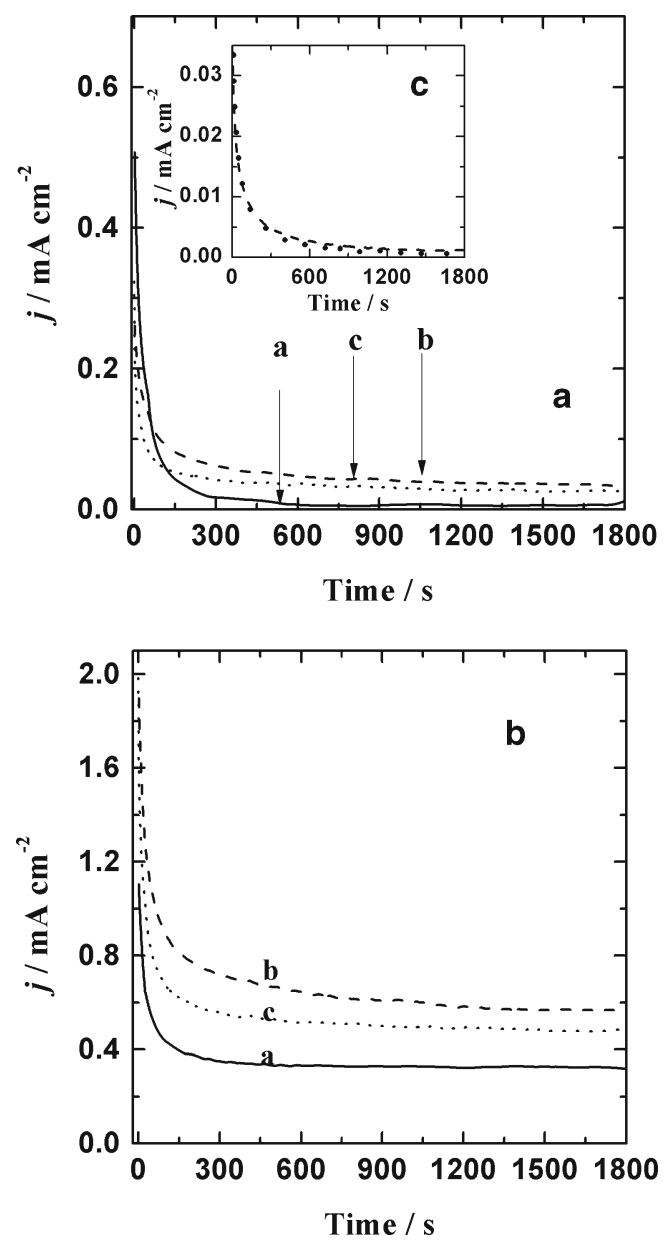

Fig. 6 Current-time responses at $0.3 \mathrm{~V}$ (a) and $0.4 \mathrm{~V}$ (b) for the oxidation of $0.5 \mathrm{~mol} \mathrm{dm}^{-3}$ ethanol at bare $\mathrm{PtRh} /$ Vulcan $(a), \mathrm{MoO}_{3}$ modified $\mathrm{PtRh} /$ Vulcan $(b)$, and $\mathrm{WO}_{3}$-modified $\mathrm{PtRh} /$ Vulcan $(c)$ catalysts. Insert $(C)$ chronoamperometric profiles of the prepared $\mathrm{WO}_{3}$ and $\mathrm{MoO}_{3}$ catalysts for ethanol oxidation recorded at $0.3 \mathrm{~V}$. Electrolyte, $0.5 \mathrm{~mol} \mathrm{dm}^{-3} \mathrm{H}_{2} \mathrm{SO}_{4}$

electrocatalysts. At $0.3 \mathrm{~V}$, the current was only developed when a metal oxide was present, which is consistent with the onset potential observed during the cyclic voltammetric oxidation of ethanol. At $0.4 \mathrm{~V}$, all three electrode systems yielded current with the sensitivities in the order $\mathrm{MoO}_{3}$-modified $>\mathrm{WO}_{3}$ modified $>$ unmodified $\mathrm{PtRh} /$ Vulcan nanoparticles. In all cases, at $0.4 \mathrm{~V}$, steady-state currents were developed in the range 510 min. It seems that the presence of metal (Mo or W) oxo species in the vicinity of PtRh nanoparticles does not preclude the ethanol adsorption (activation) step. Further, the appearance of steady-state amperometric currents implies the existence of a balance between the rates of liberation of the active sites by oxidative desorption of intermediate species that otherwise poison these sites (e.g., $\mathrm{CO}, \mathrm{CH}_{x}, \mathrm{CH}_{3} \mathrm{CHO}$, and $\mathrm{CH}_{3} \mathrm{COOH}$ ) and the adsorption of ethanol at these catalytic sites. It is known $[34,38,71-73]$ that the metal oxide $\left(\mathrm{MoO}_{3}\right.$ or $\left.\mathrm{WO}_{3}\right)$-containing environment at the electrocatalytic interface activates interfacial water at a lower potential (provide $-\mathrm{OH}$ groups on the oxide surface). This process is likely responsible for facilitating the electrooxidation of the surface poisoning intermediate species, especially $\mathrm{CO}$, which frees these sites for the oxidation of new ethanol molecules.

\section{CO-stripping diagnostic experiments}

To get some insight into the systems' abilities to remove (through oxidation) $\mathrm{CO}$ adsorbates, $\mathrm{CO}$-stripping voltammetric experiments were performed at glassy carbon electrodes modified with $\mathrm{PtRh} /$ Vulcan, $\mathrm{MoO}_{3}$-modified $\mathrm{PtRh} /$

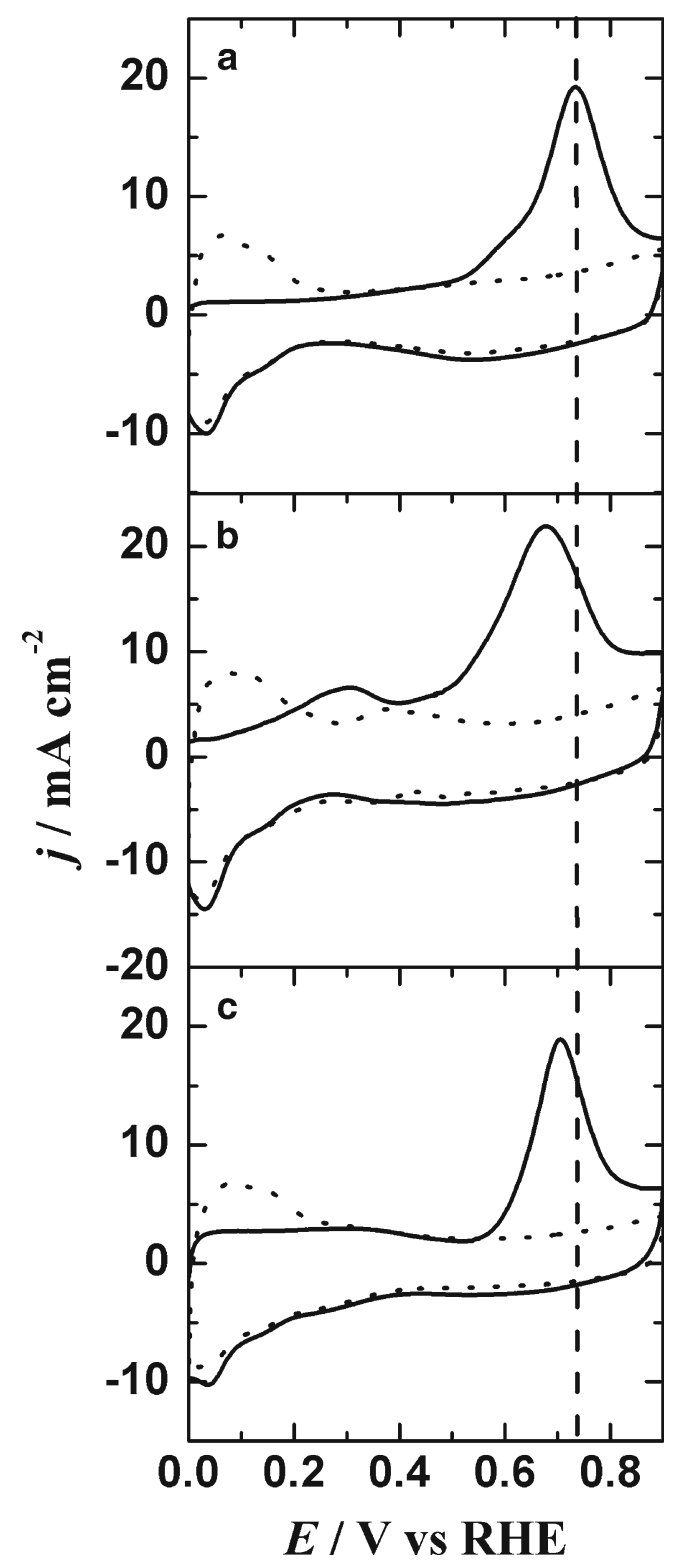

Fig. $7 \mathrm{CO}$ stripping voltammograms recorded at $10 \mathrm{mV} \mathrm{s}^{-1}$ in $0.5 \mathrm{~mol} \mathrm{dm}^{-3} \mathrm{H}_{2} \mathrm{SO}_{4}$ for the $\mathrm{PtRh} /$ Vulcan (a), $\mathrm{MoO}_{3}$-modifed $\mathrm{PtRh} /$ Vulcan (b), and $\mathrm{WO}_{3}$-modifed PtRh/Vulcan (c) catalysts. $\mathrm{CO}$ adsorption was done at $0.1 \mathrm{~V}$. The solid curve shows the first cycles, and the dotted curve shows the second cycles 
Vulcan, and $\mathrm{WO}_{3}$-modified PtRh/Vulcan catalysts (Fig. 7). The upper potential limit was chosen to avoid the overoxidation of the surface and irreversible damage to the electrocatalyst structure. As shown in Fig. 7, significant differences in the onset potentials and peak potentials for $\mathrm{CO}$ oxidation during the first anodic cycles recorded using the $\mathrm{MoO}_{3}$-modified system in relation to the $\mathrm{WO}_{3}$-modified and unmodified catalysts were observed. Moreover, in all cases, CO blocks the hydrogen adsorption-desorption region which confirms that the surface is fully covered by $\mathrm{CO}$. The position of the main CO-stripping (oxidation) peak for $\mathrm{MoO}_{3}$-modified $\mathrm{PtRh} /$ Vulcan and $\mathrm{WO}_{3}$-modified $\mathrm{PtRh} / \mathrm{Vul}$ can catalysts appeared at 0.66 and $0.70 \mathrm{~V}$, respectively. The fact that the peak was only observed during the first anodic cycle implied that all adsorbed $\mathrm{CO}$ was oxidized and removed from the surface under such conditions. At the $\mathrm{MoO}_{3}$-modified system, in comparison to the $\mathrm{WO}_{3}$-modified catalyst, the CO-oxidation peak shifted negatively by 80 and $40 \mathrm{mV}$, respectively, versus the main $\mathrm{CO}_{\text {ads }}$ electrooxidation peak $(E=0.74 \mathrm{~V})$, appearing at the bare $\mathrm{PtRh} /$ Vulcan catalyst. The obtained results were in agreement with previous observations concerning enhancement of activities of Pt and PtSn catalysts by modification or admixing with selected transition metal oxides [31, 73-75].

The electrochemically active surface area $\left(S_{\mathrm{A}}\right)$ was calculated assuming a monolayer of adsorbed $\mathrm{CO}$ on the modified $\mathrm{PtRh} /$ Vulcan catalysts and measuring the charge required to oxidize this monolayer. The latter value was calculated by integrating CO-stripping peaks and assuming that the coulombic charge was $420 \mu \mathrm{C} \mathrm{cm}^{-2}[41,75]$. The $S_{\mathrm{A}}$ values for the catalysts were 45,44 , and $42 \mathrm{~m}^{2} \mathrm{~g}^{-1}$ for bare $\mathrm{PtRh} /$ Vulcan, $\mathrm{MoO}_{3}$-modified $\mathrm{PtRh} /$ Vulcan, and $\mathrm{WO}_{3}$ modified PtRh/Vulcan, respectively. CO-stripping voltammetric investigations show that metal oxide species block only a small fraction of the electrochemically active PtRh particle surface area.

\section{Conclusions}

We have demonstrated an improvement in carbon-supported PtRh nanoparticles for the electrocatalytic oxidation of ethanol by adsorption of metal oxides $\left(\mathrm{MoO}_{3}\right.$ or $\left.\mathrm{WO}_{3}\right)$ thereon. The existence these metal oxide layers on PtRh/Vulcan nanoparticles yields higher catalytic currents for the oxidation of ethanol under voltammetric and chronoamperometric conditions and a lower potential for the onset for this process. The increased catalytic efficiency shall be related to improved removal of poisoning species such as $\mathrm{CO}_{\mathrm{ads}}$ from the active sites. So far, there is no evidence for enhanced C$\mathrm{C}$ bond splitting necessary for the oxidation of ethanol. The activation effect may also involve direct specific interactions (chemical or electronic) between metal oxides and $\mathrm{Pt}$ or $\mathrm{Rh}$ sites. It cannot be excluded that interactions between platinum or rhodium and molybdenum oxide or tungsten oxide may result in changes in the surface electronic structures and thus in changes in the adsorption energies of carbon monoxide or even ethanol on these surfaces [9]. Further research is along this line.

Acknowledgments The author acknowledges financial support from the Ministry of Science and Higher Education (Poland) under the Singapore/112/2007 collaborative project. The author would also like to thank P.J. Kulesza and J.A. Cox for helpful discussions regarding this manuscript.

Open Access This article is distributed under the terms of the Creative Commons Attribution License which permits any use, distribution, and reproduction in any medium, provided the original author(s) and the source are credited.

\section{References}

1. Wasmus S, Kuver A (1999) J Electroanal Chem 461:14-31

2. Zhang J (2008) PEM fuel cell electrocatalysts and catalyst layers: fundamentals and applications. Springer, New York

3. McGrath KM, Prakash GKS, Olah GA (2004) J Ind Eng Chem 10:1063-1080

4. Soszko M, Lukaszewski M, Mianowska Z, Czerwinski A (2011) J Power Sources 196:3513-3522

5. Vigier F, Rousseau S, Coutanceau C, Leger JM, Lamy C (2006) Top Catal 40:111-121

6. Antolini E (2007) Appl Catal B 74:337-350

7. Purgato FLS, Olivi P, Leger JM, de Andrade AR, Tremiliosi G, Gonzalez ER, Lamy C, Kokoh KB (2009) J Electroanal Chem 628:81-89

8. Kowal A, Li M, Shao M, Sasaki K, Vukmirovic MB, Zhang J, Marinkovic NS, Liu P, Frenkel AI, Adzie RR (2009) Nature Mater $8: 325-330$

9. Barczuk PJ, Lewera A, Miecznikowski K, Kulesza PJ (2010) J Power Sources 195:2507-2513

10. Miecznikowski K, Kulesza PJ (2011) J Power Sources 196:25952601

11. de Souza JPI, Queiroz SL, Bergamaski K, Gonzalez ER, Nart FC (2002) J Phys Chem B 106:9825-9830

12. Chang S-C, Leung L-WH, Weaver MJ (1990) J Phys Chem 94:6013-6021

13. Iwasita T (2002) J Braz Chem Soc 13:401-409

14. Wang H, Jusys Z, Behm RJ (2004) J Phys Chem B 108:1941319424

15. Camara GA, Iwasita T (2005) J Electroanal Chem 578:315-321

16. Leger JM, Rousseau S, Coutanceau C, Hahn F, Lamy C (2005) Electrochim Acta 50:5118-5125

17. Antolini E (2007) J Power Sources 170:1-12

18. Camara GA, de Lima RB, Iwasita T (2004) Electrochem Commun 6:812-815

19. Pacheco Santos V, Del Colle V, Batista de Lima R, Tremiliosi-Filho G (2004) Langmuir 20:11064-11072

20. Tsiakaras PE (2007) J Power Sources 171:107-112

21. Ribeiro J, dos Anjos DM, Leger JM, Hahn F, Olivi P, de Andrade AR, Tremiliosi-Filho G, Kokoh KB (2008) J Appl Electrochem 38:653-662

22. Li G, Pickup PG (2006) Electrochim Acta 52:1033-1037

23. Lamy C, Rousseau S, Belgsir EM, Coutanceau C, Leger JM (2004) Electrochim Acta 49:3901-3908 
24. Vigier F, Coutanceau C, Perrard A, Belgsir EM, Lamy C (2004) J Appl Electrochem 34:439-446

25. Jiang L, Sun G, Sun S, Liu J, Tang S, Li H, Zhou B, Xin Q (2005) Electrochim Acta 50:5384-5389

26. Thole BT, Carra P, Sette F, Van der Laan G (1992) Phys Rev Lett 68:1943-1946

27. Spinace EV, Linardi M, Neto AO (2005) Electrochem Commun 7:365-369

28. Jablonski A, Kulesza PJ, Lewera A (2011) J Power Sources 196:4714-4718

29. Li M, Kowal A, Sasaki K, Marinkovic N, Su D, Korach E, Liu P, Adzic RR (2010) Electrochim Acta 55:4331-4338

30. Ioroi T, Akita T, Yamazaki S, Siroma Z, Fujiwar N, Yasuda K (2006) Electrochim Acta 52:491-498

31. Maa L, Zhaoa X, Si F, Liu Ch, Liao J, Liang L, Xing W (2010) Electrochim Acta 55:9105-9112

32. Jayaraman S, Jaramillo TF, Baeck SH, McFarland EW (2005) J Phys Chem B 109:22958-22966

33. Kulesza PJ, Grzybowska B, Malik MA, Chojak M, Miecznikowski K (2001) J Electroanal Chem 512:110-118

34. Grgur BN, Markovic NM, Ross PN (1998) J Phys Chem B 102:2494-2501

35. Grgur BN, Markovic NM, Ross PN (1999) J Electrochem Soc 146:1613-1619

36. Samjeske G, Wang H, Loffler T, Baltruschat H (2002) Electrochim Acta 47:3681-3692

37. Zhang HQ, Wang Y, Fachini ER, Cabrera CR (1999) Electrochem Solid-State Lett 2:437-439

38. Wang Y, Fachini ER, Cruz G, Zhu YM, Ishikawa Y, Colucci JA, Cabrera CR (2001) J Electrochem Soc 148:C222-C226

39. Mylswamy S, Wang CY, Liu RS, Lee JF, Tang MJ, Lee JJ, Weng BJ (2005) Chem Phys Lett 412:444-448

40. Mukerjee S, Lee SJ, Ticianelli EA, McBreen JB, Grgur N, Markovic NM, Ross PN, Giallombar-do JR, de Castro ES (1999) Electrochem Solid-State Lett 2:12-15

41. Santiago EI, Camara GA, Ticianelli EA (2003) Electrochim Acta 48:3527-3534

42. Zurowski A, Kolary-Zurowska A, Dsoke S, Barczuk PJ, Marassi R, Kulesza PJ (2010) J Electroanal Chem 649:238-247

43. Barczuk PJ, Lewera A, Skorupska K, Ping Jiang S, Li Ch, Kulesza PJ (2011) Electrocatal 2:52-59

44. Lewera A, Barczuk PJ, Skorupska K, Miecznikowski K, Salamonczyk M, Kulesza PJ (2011) J Electroanal Chem 662:93-99

45. Wang D, Lu S, Kulesza PJ, Li ChM, Marco R, Jiang SP (2011) Phys Chem Chem Phys 13:4400-4410

46. Watanabe M, Motoo SJ (1975) J Electroanal Chem 60:267-273

47. Watanabe M, Motoo SJ (1975) J Electroanal Chem 60:275-283

48. Wang J, Yin G, Shao Y, Zhang S, Wang Z, Gao Y (2007) J Power Sources 171:331-339
49. Zhou W, Zhou Z, Song S, Li W, Sun G, Tsiakaras P, Xin Q (2003) Appl Catal B 46:273-285

50. Radmilovic V, Gasteiger HA, Ross PN (1995) J Catal 154:98-106

51. Lima FHB, Gonzalez ER (2008) Electrochim Acta 53:29632971

52. Martinez-Huerta MV, Rodriguez JL, Tsiouvaras N, Pena MA, Fierro JLG, Pastor E (2008) Chem Mater 20:4249-4259

53. Al Mohammad A, Gillet M (2002) Thin Solid Films 408:302-309

54. Choi YG, Sakai G, Shimanoe K, Miura N, Yamazoe N (2002) Sens Actuators B 87:63-72

55. Baltrus JP, Makovsky LE, Stencel JM, Hercules DM (1985) Anal Chem 57:2500-2503

56. Gupta SS, Datta J (2006) J Electroanal Chem 594:65-72

57. Ribeiro J, dos Anjos DM, Kokoh KB, Coutanceau C, Leger JM, Olivi P, de Andrade AR, Tremiliosi-Filho G (2007) Electrochim Acta 52:6997-7006

58. Ioroi T, Fujiwara N, Siroma Z, Yasuda K, Miyazaki Y (2002) Electrochem Commun 4:442-446

59. Elezovic NR, Babic BM, Radmilovic VR, Gojkovic SL, Krstajic NV, Vracar LM (2008) J Power Sources 175:250-255

60. Dos Anjos D, Kokoh KB, Leger JM, Andrade AR, Olivi P, Tremiliosi-Filho G (2006) J Appl Electrochem 36:13911397

61. Gojkovic SL, Tripkovic AV, Stevanovic RM, Krstajic NV (2007) Langmuir 23:12760-12764

62. Lebedeva NP, Janssen GJM (2005) Electrochim Acta 51:29-40

63. Mikhailova AA, Pasynskii AA, Dobrokhotova ZV, Grinberg VA, Khazova OA (2008) Russ J Electrochem 44:303-312

64. Kuznetsov VV, Kalinkina AA, Maksimov YM, Podlovchenko BI (2009) Russ J Electrochem 45:1211-1214

65. Ordonez LC, Roquero P, Sebastian PJ, Ramirez J (2005) Catal Today $107-108: 46-52$

66. Mukerjee S, Urian RC (2002) Electrochim Acta 47:3219-3231

67. Roquero P, Ordonez LC, Herrera O, Ugalde O, Ramirez J (2007) Int J Chem React Eng 5:1-9

68. Wang MY, Chen JH, Fan Z, Tang H, Deng GH, He DL, Kuang YF (2004) Carbon 42:3257-3260

69. Hitmi H, Belgsir EM, Leger JM, Lamy C, Lezna RO (1994) Electrochim Acta 39:407-415

70. Fujiwara N, Friedrich KA, Stimming U (1999) J Electroanal Chem 472:120-125

71. Shen PK, Tseung ACC (1994) J Electrochem Soc 141:3082-3090

72. Yang LX, Bock C, MacDougall B, Park J (2004) J Appl Electrochem 34:427-438

73. Manzo-Robledo A, Boucher AC, Pastor E, Alsono-Vante N (2002) Fuel Cells 2:109-116

74. Jiang L, Colmenares L, Jusys Z, Sun GQ, Behm RJ (2007) Electrochim Acta 53:377-389

75. Wang ZB, Zuo PJ, Yin GP (2009) Fuel Cells 9:106-113 